Article

\title{
From Ideal Proposals to Serial Developments: Victor Bourgeois's Schemes in the Light of Post-War Developments in Brussels
}

\author{
Gérald Ledent \\ Faculté d'Architecture, d'Ingénierie Architecturale, d'Urbanisme (LOCI), UCLouvain, 1060 Brussels, Belgium; \\ E-Mail: gerald.ledent@uclouvain.be
}

Submitted: 31 March 2019 | Accepted: 24 June 2019 | Published: 30 September 2019

\begin{abstract}
Three essential elements of modernism consolidated through war: a centralised welfare state, a serial industrial apparatus and, often, a territorial tabula rasa. Hence, for many modernist architects and urban planners, post-war Europe became the ideal ground to put their ideas to the test. However, there is a genuine discrepancy between the proposals of the first four Congrès Internationaux d'Architecture Moderne (CIAM) and what was massively implemented throughout Europe after 1945. To explore this divergence, Brussels proves to be an interesting case study for two main reasons. First, it hosted the third CIAM in November 1930, where Victor Bourgeois presented his views on housing and cities, in line with the ideals of the time. Second, after the war, Belgium, like many Western countries, experienced a period of euphoria, during which the modernist ideology attained a sudden and broad consensus. In the capital over the following three decades new infrastructure was built, as well as housing developments that derived, at least formally, from the CIAM ideals. This article explores the gap between the ideals and the reality of modernism through a comparison on two scales: the city and housing. Bourgeois's Grand and Nouveau Bruxelles proposals are compared to the Manhattan Plan and Etrimo's housing developments. Understanding the gap between the ideals of modernism and its implementation may help identify characteristics of the modernist movement but also, as Lacaton-Vassal pointed out when citing Habermas, complete the "unfinished project" (Habermas, 1984) of modernism.
\end{abstract}

\section{Keywords}

Brussels; Etrimo; Groupe Structures; Manhattan Plan; modernist architecture; modernist housing; Victor Bourgeois

\section{Issue}

This article is part of the issue "Housing Builds Cities", edited by Luca Ortelli (École Polytechnique Fédérale de Lausanne, Switzerland), Chiara Monterumisi (École Polytechnique Fédérale de Lausanne, Switzerland) and Alessandro Porotto (École Polytechnique Fédérale de Lausanne, Switzerland).

(C) 2019 by the author; licensee Cogitatio (Lisbon, Portugal). This article is licensed under a Creative Commons Attribution 4.0 International License (CC BY).

\section{Building Modernism?}

\subsection{A Fertile Ground}

Modernist architects considered the city an inseparable body, tying in the same reflexion the scale of furniture, domestic spaces and territory (Gropius, 1925a). Accordingly, architects had to be the "organizers of all the human needs in the city" (Bourgeois, 1931b, p. 169). Urban planning and housing design were adjusted to the social progress of modern societies. Like never before, architecture was to reshape society comprehensively.
Although reflection on cities had been a leitmotiv in architecture history, modernism elaborated for the first time a thorough and explicit consideration of ordinary domestic architecture. Whereas theorists-Serlio, Le Muet, Blondel, Brisieux, Jombert, etc.-had considered domestic architecture in the past, it had never been a central issue (Ledent, 2014). By the end of the 19th century, the "housing crisis" had become so acute that it literally became the battle cry of the architectural avantgarde (Teige, 1932).

This determination to reshape both housing and urban planning was developed comprehensively in the 
first four Congrès Internationaux d'Architecture Moderne (CIAM). The congresses summed up the views of modernist architects on housing and urban planning, albeit with a few discordant voices (Mumford, 2002). However, if modernist architects developed radical and innovative solutions regarding urban planning and housing design, their ideas were only implemented marginally in the interbellum due to economic crises, political unrest and a lack of understanding among the population. In these troubled times, modernism remained primarily rhetorical (Heynen, 2000). Hence, it is no coincidence that Huib Hoste, one of Belgium's leading architects in the interwar period, wrote the play If I Was a Dictator (Hoste, 1937), illustrating the frustration of modernist architects to carry out their ideology.

World War II brushed aside these hindrances. Along with the economic boost provided by the Marshall Plan in Western Europe, the conjunction of three factors enabled the execution of modernism (Voyé, 1998). First, the modernist ideology relied on powerful regimes since "urban design cannot be realised without a strong authority" (Verwilghen, 1934). This strong political lever emerged in the form of centralised welfare states. Secondly, a serial industrial apparatus was developed through war that could easily be redirected to the construction industry. Thirdly, war-torn territories offered the long-coveted tabula rasa. Hence, upon the end of the war, everything was in place to carry out the modernist project.

\subsection{Discrepancies}

Nevertheless, when the conditions finally met the needs of the modernist rhetoric, a distortion seemed to occur. Indeed, there is an undisputable discrepancy between the pioneering ideas of the first four CIAMs and what was massively implemented throughout Europe after 1945. A comparison of Le Corbusier's Unité d'Habitation and the French Grands Ensembles clearly illustrates this difference.

This article seeks to identify and understand the discrepancies between the ideals of pre-war modernism and what was actually built. This distinction is essential since the critics of modernism often erroneously confuse what was produced on its behalf with the ideology itself. Identifying these differences allows for a clearer definition of modernism and how its production can be addressed today.

\subsection{Brussels}

To assess this question, a comparison of the first four CIAM proposals and their effective implementation is drawn in the case of Brussels. This city is paradigmatic for several reasons. First, Brussels's traditional housing and urban planning completely contradict the precepts of modernism (Ledent \& Komossa, 2019). Second, Brussels hosted the third CIAM in November 1930 in which de- bates focused largely on housing (Steinmann, 1979). Victor Bourgeois, who organised the congress, presented his plans for the Nouveau Bruxelles in line with the ideals of the time, elaborating further on the Grand Bruxelles developed a few years earlier. Third, Belgium experienced a period of euphoria after the war, in which the pre-war modernist ideology enjoyed a sudden and broad consensus. This trend led to vast urban destruction; as Bourgeois declared before his death in 1962, Brussels "was never destroyed by the war itself but rather by its own people" (Hanrion, 2015), a phenomenon embodied by the term Bruxellization.

\section{Comparison of Modernism in Brussels}

This analysis of modernism in Brussels is twofold. It explores its interbellum proposals with its actual post-war construction at urban and domestic scales.

On the one hand, modernism is identified through the precepts advocated by the first four CIAMs. These ideas are illustrated in proposals for the capital by Victor Bourgeois. The choice of Bourgeois is not accidental. He was a central figure of modernism in Belgium and abroad through his writings, visionary schemes built projects (Strauven, 2015). He advocated a clear rupture with academism, as he literally "tore his diploma apart in front of the school jury" (Strauven, 2015, p. 60). As a practitioner, his Cité Moderne, from 1925, and later his participation in the Weissenhof in Stuttgart helped establish Belgium on the modernist architectural scene (Strauven, Culot, \& De Gobert, 2005). Moreover, Bourgeois was one of the few Belgian architects of his time to develop schemes at the scale of both housing and that of the city. In addition, he was a founding member of the CIAM and attended most CIAM and CIRPAC (the Comité International pour la Résolution des Problèmes de l'Architecture Contemporaine) meetings before 1945. He even chaired the La Sarraz meeting (Bourgeois \& Flouquet, 1952), replacing Karl Moser as president. Furthermore, the third CIAM, which Bourgeois hosted in Brussels in 1930, was undoubtedly the main architectural event of the interbellum in Belgium. Finally, Bourgeois was not only a practitioner and a theorist but also a communicator. He cofounded 7 Arts, a journal intended to communicate revolutionary thinking about the arts (Bourgeois \& Flouquet, 1952).

One the other hand, post-war modernism is evaluated through two paradigmatic projects: the Manhattan Plan and Etrimo's real estate developments. The Manhattan Plan was selected for its symbolic impact on the city, generating fervent debates for the next 50 years (Martens, 2009; Romańczyk, 2012) and eventually prompting alternative thinking regarding city planning through participation (Schoonbrodt, 2007). The plan, moreover, provides the ideal counterpoint to Bourgeois's Grand Bruxelles since it is set in the same area of the city. Etrimo, for its part, was chosen because it was the largest post-war housing developer in Brussels, 
in terms of quantity but also in the collective psyche. Even though Etrimo was founded in the 1930s, producing a series of elegant residential buildings, its most paradigmatic production occurred in the 1950s and 1960s (Broes \& Dehaene, 2016).

In order to be compared objectively, all of the above schemes were redrawn in a similar fashion. The literature on the projects was also thoroughly analysed to dissect the underlying motives of the various stakeholders (architects, developers, politicians, etc.).

\section{Interbellum and Post-War Schemes}

\subsection{From Rhetorical to Pragmatic Modernism}

After World War I, many people strongly believed that modernist architecture could revolutionize human societies (Strauven et al., 2005). The need for housing was acute and the first CIAM congresses explicitly addressed this issue. In Belgium, the CIAM exerted an important influence through its leaders Victor Bourgeois, Huib Hoste, Louis-Herman De Koninck, Renaat Braem, Raphaël Verwilghen, etc., but also through the editorial line of L'Equerre and Opbouwen. Nevertheless, most projects remained unbuilt and theoretical (Beekaert \& Strauven, 1971) such as the linear city of Braem in 1934, the competition for the east bank of Antwerp in 1933 and the administrative buildings on the central avenues of Brussels by Jasinski in 1930. As an active member of the CIAM, Bourgeois developed and exhibited several proposals illustrating his visions of both urban planning and housing. Like those of his peers, his proposals remained rhetorical.

Hence, however innovative, modernism did not enjoy any interbellum large-scale implementation. Nevertheless, after 1945, in most Western countries, the whole state apparatus endorsed modernism with a technocratic vision of reconstruction. The 1958 World Fair marked a turning point for modernism in Brussels, as Belgium had clearly set standards for its reconstruction ambitions, resolutely and unanimously moving towards modernity. The capital underwent a vast modernisation process (Hubert, 2008). Brussels was seen as the "crossroads of the West" (Ministère des travaux publics et de la reconstruction, 1955) and began playing a major international role as the provisional host of the European institutions in 1958 and, a decade later, headquarters of NATO, in 1967. In Brussels, two main construction fields opened up. On the one hand, new infrastructure was built. Everything was based on the automobile and major roads were created to make everything car-accessible. The interbellum theories of the functional city were applied to (re)designing Brussels, separating functional zones and dismantling entire neighbourhoods in the old city centre (de Saulnier, 1963). On the other hand, housing was produced on a large scale, in accordance with, at least formally, the principles of modernism.

The pre- and post-war schemes and their theoretical underpinnings are analysed here, explaining which con- texts, spatial and programmatic levers they relied on. To identify their shifting features easily and allow for a comparative reading, they are presented successively on urban and housing scales.

\subsection{Urban Schemes}

\subsubsection{Grand and Nouveau Bruxelles}

While Bourgeois built several state-of-the art projects in the early 1920s, commissions started decreasing by the end of the decade (Strauven, 2015). Bourgeois focused subsequently on theoretical plans for Brussels, to illustrate his views on urban planning to his CIAM peers. They were not meant as definitive plans but rather a "base for discussion" (AAM, 1971) to renew the urban planning tradition. Bourgeois produced then the first Belgian urban projects in line with the CIAM. In these schemes, he distinguished two modes regarding urban planning (Strauven, 2015): a reforming mode in the city centre, and a revolutionary mode in the suburbs or destroyed territories.

Two exploratory projects illustrate clearly these modes: Grand Bruxelles, from 1929, and Nouveau Bruxelles, from 1930. While Bourgeois' ideas on urban planning for Brussels date back to a few years earlier (Bourgeois, 1927), his first comprehensive reflections are demonstrated in his 1929 project for Grand Bruxelles (Figure 1), exhibited at the Cercle Artistique et Littéraire and published the following year (Bourgeois, 1930). It originated in the debate around the north-south railway connection, a long-time problem in Brussels. According to Bourgeois, the solutions developed at the time (and executed 30 years later) were too limited, old-fashioned and inefficient in terms of mobility. Moreover, they destroyed large parts of the city centre, cutting through the first Brussels city walls. His proposal relied on three main elements. First, he drew a new railway along the Boulevard du Midi and then parallel to the canal through the centre, outside the first city walls, on the extension of the Allée Verte. In doing so, Bourgeois preserved the inner centre, which was being targeted for demolition. Meanwhile, he reconsidered the entire traffic system by creating a hierarchy of "efficient" roads between autostrades for fast traffic and canaux de promenade for pedestrians (Bourgeois, 1930). Second, Bourgeois created two distinctive railway stations for which he provided a meticulous description: an international hub was created in the north of the city, coupling rail, air and road networks and hosting new urban developments, while the existing North Station itself was moved closer to the canal and devoted only to national traffic; there was no trace of what was to be the Central station, which today lies in the middle of the city centre. Third, while streets and stations were represented comprehensively, the domestic fabric was only briefly described. Bourgeois designed a new neighbourhood of small high-rises to replace an entire district of the North Quarter, just as his 


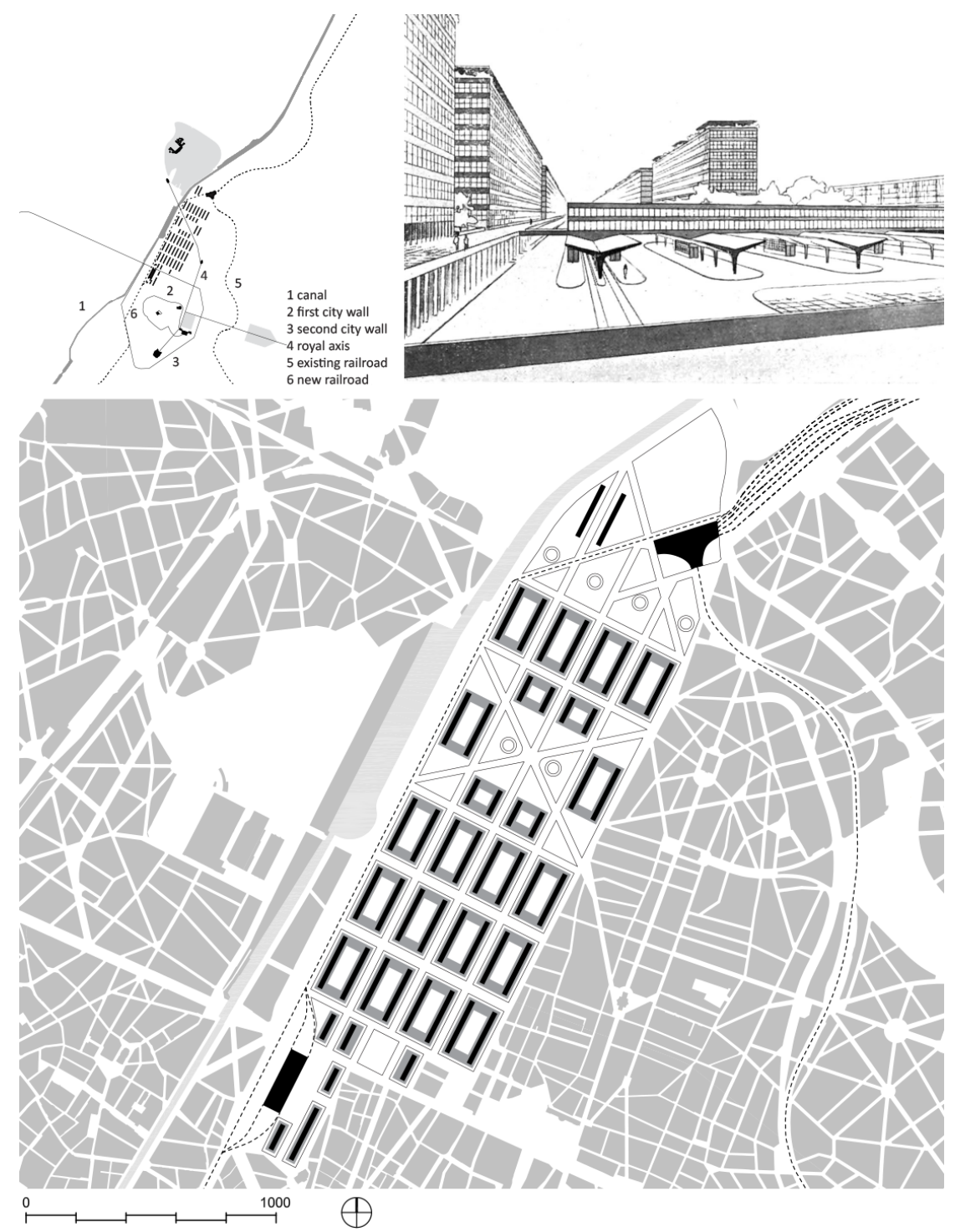

Figure 1. Bourgeois, Le Grand Bruxelles, 1929 (drawings by the author; perspective drawing by Bourgeois, 1930, p. 175).

CIAM peers advocated substituting "the existing urban pattern in favour of widely spaced high-rises" (Mumford, 2002, p. 58). Dwellings are contained in 11-storey buildings oriented north-south and linked in pairs by doubleheight plinths to create genuine urban blocks. Bourgeois insisted on the "cost effectiveness of this public development" that was only possible through "high and important constructions" (Bourgeois, 1930, p. 176).

While Grand Bruxelles illustrated a reforming mode, Bourgeois adopted a revolutionary mode in Nouveau Bruxelles (Figure 2) that was presented at the CIAM 3 in 1930 (Bourgeois, 1931a; Giedion, 1931). Rather than reorganising the existing circulations in the centre, Bourgeois suggested adding a new neighbourhood to the city. This new urban development was based north of the city, along the Senne Valley, on the western bank of the canal. Its structure was in complete opposition to the traditional city. Bourgeois proposed a 25,000-dwelling development divided into four residential zones by a large cross-shaped public green zone fea- turing leisure and community facilities. Housing is accommodated in long ten-story buildings, free-standing in green spaces in the immediate vicinity of services such as kindergartens, playgrounds, parking lots, etc. Commercial spaces are sheltered in the ground floors of these buildings. Interestingly, the four quadrants of the "functional city", which became the "dominant concept on urban planning after the Brussels' meeting" (Mumford, 2002, p. 59), can be traced back to Bourgeois' urban schemes and more specifically to his Nouveau Bruxelles. Indeed, there is a clear zoning in Bourgeois's plan, identifying four urban functions. Similar to Le Corbusier's Ville Contemporaine de Trois Millions d'Habitants (1922), streets are drawn according to a hierarchical grid, assigning specific place to cars and pedestrians. Housing is clearly defined in the four zones. Leisure activities are also very well identified at the heart of the plan, in the shorter branch of the central crossshaped green zone. Finally, work areas are not specified in the neighbourhood plan. However, as Bourgeois men- 


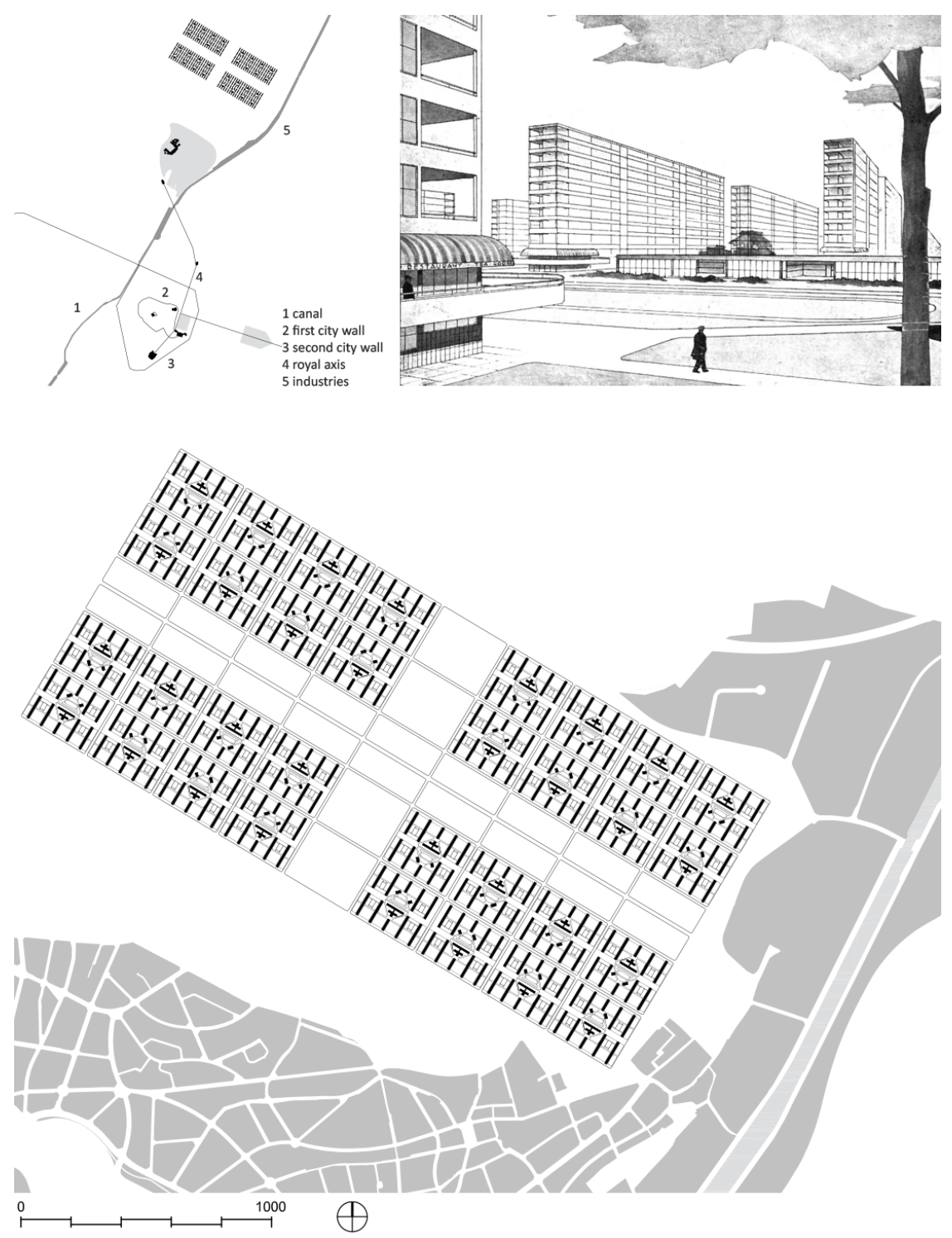

Figure 2. Bourgeois, Le Nouveau Bruxelles, 1930 (drawings by the author; perspective drawing by Bourgeois, 1931a, p. 412).

tions in his description of Nouveau Bruxelles that "the work areas are generally set to the east of the canal, hence, our residential neighbourhood should be set to the west, to be protected from the smoke of factories" (Bourgeois, 1931a). The factories' location is also visible in a perspective drawing complementing the urban scheme of Nouveau Bruxelles (Bourgeois, 1931a, p. 411).

Between Bourgeois's reforming and revolutionary schemes, a series of differences can be noted. Firstly, the second scheme no longer acknowledges pre-existing alignments. While Grand Bruxelles recognises the city's main axes and uses the existing railway routes as a project lever, Nouveau Bruxelles has an independent circulation system of its own-Bourgeois offered no clue about its links to the city. Secondly, this next development is suggested as an autonomous ensemble. While Grand Bruxelles has a clear connection to the centre, Nouveau Bruxelles could be set anywhere and pays little attention to the existing urban fabric. Thirdly, the 1930 project does not consider the existing topography, presenting an isotropic scheme on a piece of land that is, in reality, far from being horizontal. Fourthly, the city block and the street structures that could still be found in Grand Bruxelles disappear completely and are replaced by freestanding buildings on open and grassy land in Nouveau Bruxelles.

Bourgeois's consideration of the city did not end with Nouveau Bruxelles and were further pursued in the Cité Mondiale (Otlet, 1931), where he established Brussels as a major international centre. Later, Bourgeois even created a journal named Bruxelles that focused on urban issues.

\subsubsection{The Manhattan Plan}

The Manhattan Plan is exemplary of the many urban projects that were carried out in Brussels after World War II. Interestingly, it is set in the same area as 
Bourgeois's Grand Bruxelles. Before the war, it was a lively neighbourhood due to its proximity to the centre and the industries along the canal (Dessouroux, 2008). However, at the end of the 1930s, the wealthiest population started leaving the neighbourhood and was replaced by first-generation migrants (Martens \& Vanden Eende, 1994). In addition, already isolated from the city by the canal to the west and train tracks to the north, the North Quarter became even more secluded in the late 1950s. In 1956, its eastern side was demolished to build elevated train tracks, creating a border to the east. In addition, an automobile viaduct was built on the inner ring road in 1957, cutting off its southern connections. The enclave then became a speculative object for real estate tycoons such as Charly De Pauw, and two plans were set forth by Groupe Structures (Braeken, 2003). The first plan (from 1962) displayed ten office towers and luxurious apartments on the extension of Boulevard Jacqmain. However, it was quickly rejected by Brussels's strongman and Belgium's prime minister Paul Vanden Boeynants because it was "not grand enough" (Martens \& Vanden Eende, 1994). In 1964, Groupe Structures presented a second plan - the Manhattan Plan (Figure 3)that was unanimously approved by the three affected municipalities, building on the euphoria of the time. It comprised a much larger scope (53ha) and was based on the principles of the pre-war CIAMs. First, it staged a clear distinction between pedestrian lanes - resting on a 13-meter-high plinth-and automobile traffic. Second, the new area was developed around a motorway interchange. These 60-meter-wide motorways were designed on the extension of Boulevard Jacqmain and in direct connection to the ring road around Brussels. Eventually, the buildings were projected on the site as towers and slabs,

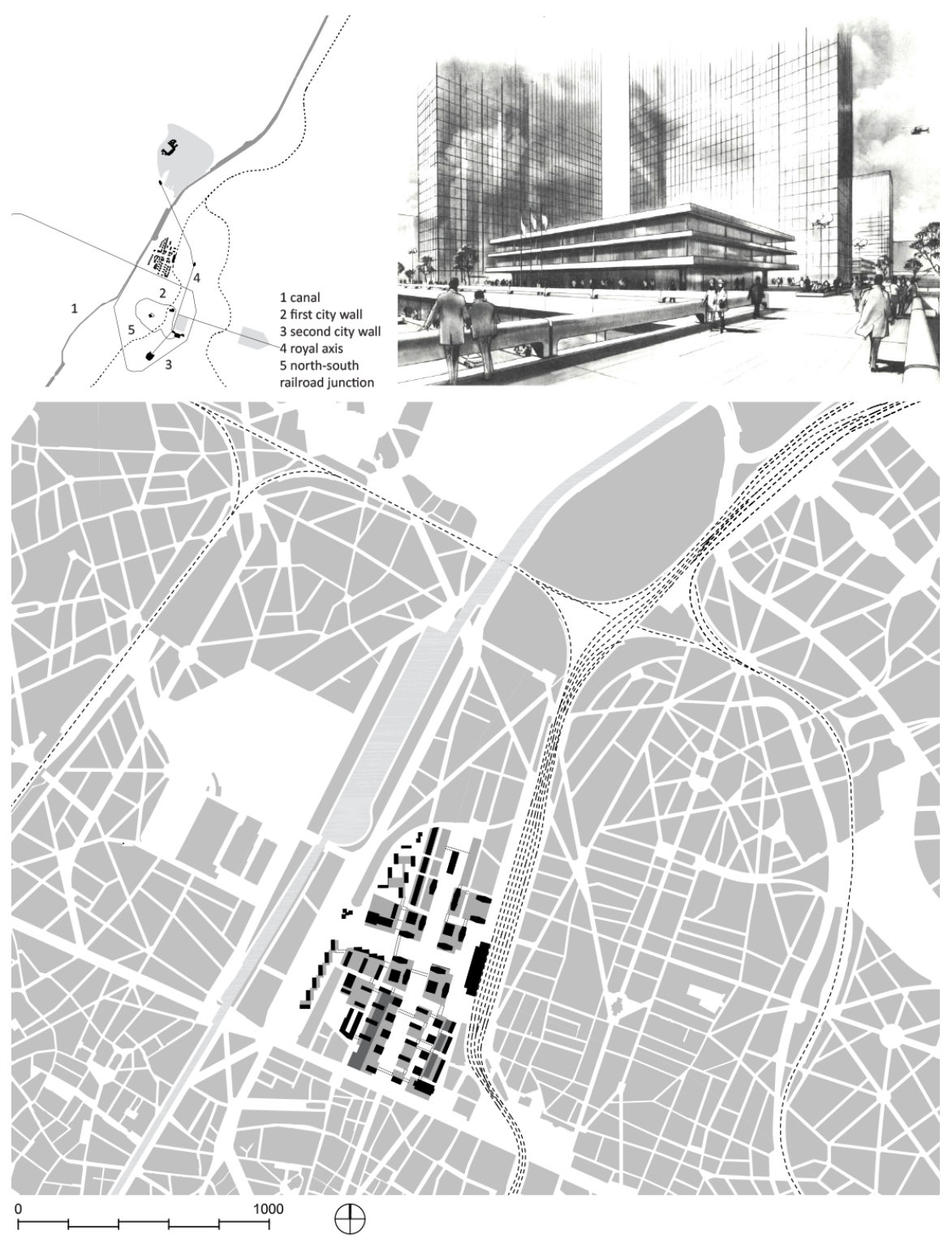

Figure 3. Groupe Structures, Plan Manhattan, 1964 (drawings by the author and perspective drawing by Groupe Structures, 1967; Demey, 1992, p. 28). 
54 in total and towering between 18 and 162 meters. The quarter was meant primarily for office buildings. Despite protests from inhabitants, expulsions started in 1969 and a vast majority was never relocated. However, while the neighbourhood was entirely torn down in a few years, the crises of the 1970s put an end to construction, generating a desolated area in the heart of the city. It was not until the second half of the 1990s that this project was completed.

Interestingly, when the 1958 World Fair opened, Bourgeois was very dubious about the actual levers of the welfare state, since "eventually facing construction deadlines, the state is not free to take important decisions...because big business is not willing to negotiate" (AAM, 1971, p. 11). Bourgeois's late prediction would prove right as "urban planning from 1955 to 1979 resembles the quintessence of untrammelled liberalism" (Dessouroux, 2008, p. 114).

\subsection{Residential Schemes}

\subsubsection{Victor Bourgeois}

With industrialisation, (mass) housing became the priority of modernist architects (Gropius, 1925b). Two trends are advocated by the first three CIAMs. On the one hand, dwelling surfaces should be (Existenz)minimum, produced in large series and complemented by collective equipment (CIAM II, 1930). On the other hand, even though this aspect was fiercely debated in Frankfurt and Brussels, housing should be in "high houses in the quiet and greenery" (Steinmann, 1979, p. 101).

Bourgeois's views on housing were clearly illustrated at the second and third CIAMs. In Frankfurt, Bourgeois presented a design (Figure 4) that he drew in 1927 as an extension of the Cité Moderne (CIAM II, 1930). The scheme displays a series of low-building slabs with a

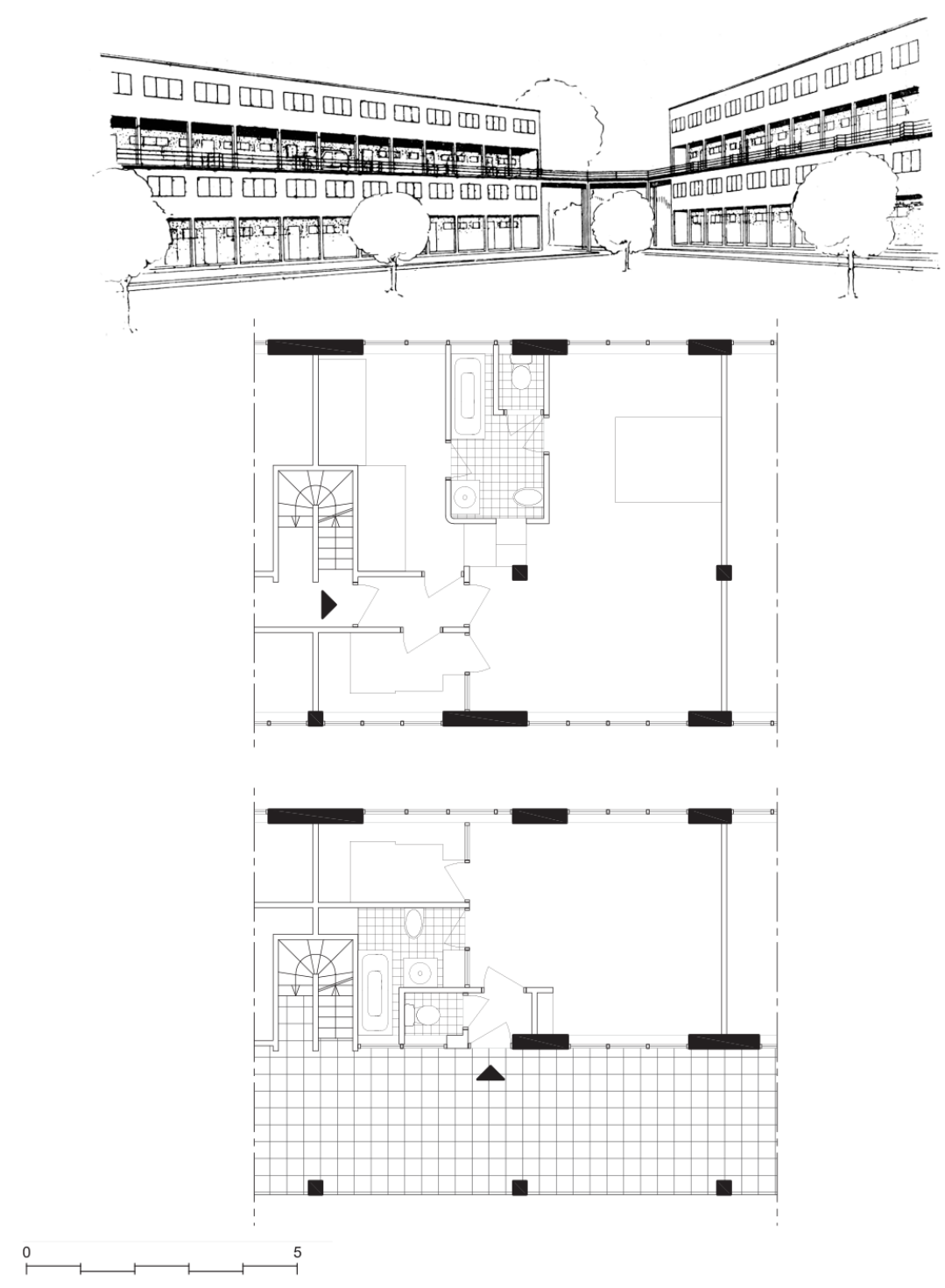

Figure 4. Bourgeois, Project for a garden city, 1927, later published in Die Wohnung für das Existenzminimum (drawings by the author and perspective drawing by Victor Bourgeois; Anonymous, 1929, p. 152) 
car-accessible gallery on the second floor (Anonymous, 1929). This gallery gives access to two types of housing: four- and two-person dwellings. Both types are minimal $\left(27.5\right.$ and $\left.47 \mathrm{~m}^{2}\right)$ and everything is designed rationally, from the narrow kitchens to the $8.8 \mathrm{~m}^{2}$ bedroom shared by two children. Built-in cupboards are located throughout the apartments to limit the use of imported furniture. The dwellings are characterized by a complete absence of corridors or hallways. Moreover, there is no separation between the main sleeping places and the living rooms. Finally, the buildings are very narrow (around $7 \mathrm{~m}$ ) to allow as much light as possible in the dwellings.

Later, in his schemes for Nouveau Bruxelles (Figure 5), the apartment buildings recall the designs of Ginzburg and Le Corbusier. Each building consists of a simple "neutral structure" enabling a "wide range of spatial arrangements" (Bourgeois, 1931a, p. 396). The first two floors are intended for commercial use. Above, the dwellings are organized in duplexes accessible on every other floor by a wide interior corridor in the middle of the buildings. Wide terraces off the living spaces allow light to enter di- rectly this collective circulation. All modern comforts are foreseen: "rational kitchen equipment", bathrooms, but also a supply line for goods. Finally, gardens, sports facilities, and sun decks are on the roofs.

Both Bourgeois's proposals oppose the traditional Brussels housing type. First, they dismiss the closed urban block that provided front-back positions for each dwelling. On the contrary, the projects display isolated buildings surrounded by greenery, following a north-south orientation as advocated by Gropius (1931). Second, collective living replaces the individual character of the traditional houses, because "the regime of isolated habitations is obsolete" (Bourgeois, 1931a, p. 402; Steinmann, 1979). Hence, individual living is reduced to its core and counterbalanced by a series of collective amenities: laundry, shops, guest bedrooms, sport facilities, solaria, etc. (Steinmann, 1979). Third, the relatively high skyline of Nouveau Bruxelles contrasts with the low-rise character of traditional Belgian cities. While the subject of debates on efficiency (Smets, 1977), highrise residential buildings bear the symbolic mark of the

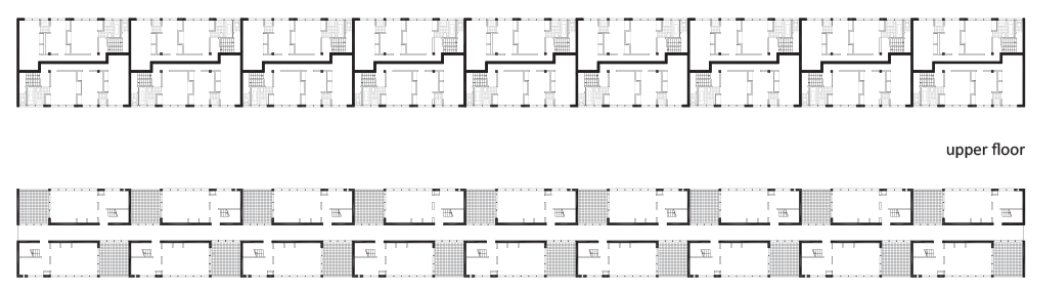

gallery floor
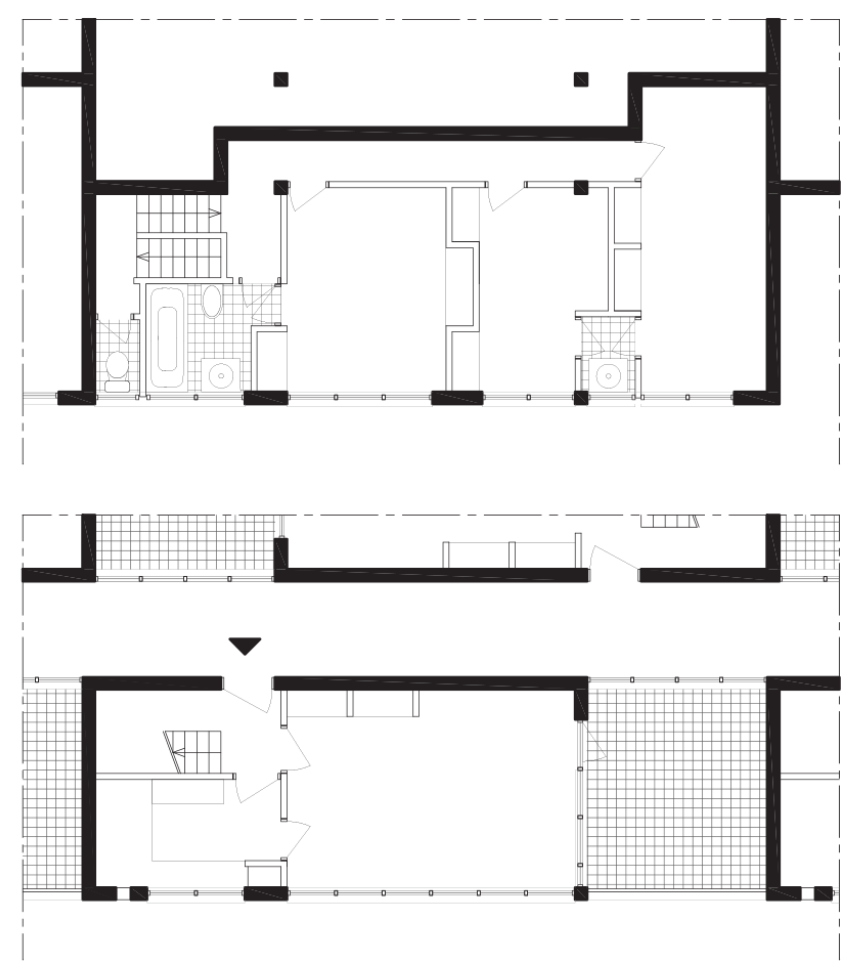

$\stackrel{0}{1}$

Figure 5. Bourgeois, Le Nouveau Bruxelles, 1930 (drawings by the author). 
proletarian revolution; until then high buildings were reserved for the bourgeoisie (Bourgeois, 1931a). These multi-storey buildings are considered community houses. Finally, Bourgeois's arrangements are defined according to their domestic functions. Each room's dimensions and location are determined by its purpose, which is deduced from ergonomic studies (Bauer, 1934; Steinmann, 1979). Circulation space, too, has to be rational; as Pierre Jeanneret puts it, "economic and smooth circulation is the key to contemporary architecture" (Steinmann, 1979, p. 60).

\subsubsection{Etrimo}

In terms of housing, the reconstruction period addressed a shortage of about 300,000 dwellings (Noël, 2009). Two major laws attended to this issue, either promoting private property-Law De Taye 1948-or encouraging public housing-Law Brunfaut 1949. A few years later, another regulation-Law De Taye 1953-was passed in order to fight unhealthy living conditions. In addition, from 1956, state interventions were limited to developments of 25 or more dwellings (Schoonbrodt, 1979). This series of laws led to the construction of large estates. In the city centre, mass demolition of working-class neighbourhoods was carried out and, on the outskirts, large properties were sold to provide space for tall and isolated buildings set in green surroundings. Housing was grafted directly onto the newly built road infrastructure (Dessouroux, 2008), allowing people to live among greenery while staying directly connected to the centre. In the public sector, the Cité Modèle literally incarnates modernism. It was organized according to CIAM principles as an "island of order and clarity", in opposition to the "chaos" of the traditional city (Strauven \& Braem, 1985, p. 75 ). It was meant to be an autarkic "model", but eventually most of its collective amenities were not built. However exemplary, the Cité Modèle remains an exception in Brussels.

Post-war modernism in the housing sector is best illustrated in the private developments of apartment buildings, because of their higher impact on the city in terms of number (more than twice as many dwellings were erected in the private as in the social sector). Beginning in the 1950s, a series of private developers produced housing of exceptional homogeneity that clearly impacted the collective consciousness (Brauman et al., 1982). These developers worked on large lots, chiefly on the city outskirts. Among them, Etrimo stands out. It was founded in the 1930s (Etrimo, 1949) and became a major actor on the housing scene from the 1950s through the 1970s. Its founder, Jean-Florian Collin, wanted to revolutionise the housing market by providing a comprehensive service to "customers", from the purchase of the land to the management of trustees. Etrimo's sales brochures relentlessly repeated the motto: "A dwelling in a park...accessible by car" (Etrimo, 1963). This formula was a resounding success: in the golden sixties, ev- ery other person leaving the trade booths had bought a dwelling.

In the 1950s, Groupe Urbanisme-Etrimo's in-house architectural firm-elaborated architectural products that would undergo very few changes. All building configurations were identical apart from variations in the finishing materials according to the social target groups. Collin was a staunch liberal who believed that the key to emancipation was homeownership for all social classes (Collin, 1938). In Brussels alone, Etrimo built over 14,000 dwellings at a pace of more than 1,200 units per year (Etrimo, 1963) in three kinds of estates: villas, bungalows and buildings in a park (Etrimo, 1963, 1965). In general, they consisted of unitary developments on large lots. In the absence of legislation concerning building heights or density, or simply ignoring them when they existed (Broes \& Dehaene, 2016), Etrimo negotiated directly with local authorities, playing therefore a decisive role in the second belt development of the city (Figures 6 and 9).

For technical and economic reasons these apartment blocks were generally limited to 12 floors above an underground garage. In the beginning, several common services such as laundries, community rooms and a caretaker's dwelling were attached to each circulation core. The rectangular buildings repeatedly had a northsouth orientation, with narrow balconies along their two main facades (Figure 7). Four identical flats, often mono-oriented, were organized around a minimal vertical nucleus in a much broader building than Bourgeois's. This arrangement was replicated two to four times in a row depending on the possibilities of the plots. Several dozens of these identical buildings were built throughout the city.

Etrimo's expansion ended in a resounding bankruptcy in 1970, engendering a new law to protect homeowners from off-plan purchases-Law Breyne 1971. However, the vacuum left by Etrimo was quickly filled by other real estate tycoons such as Amelinckx, Broens and Ruttiens. Their housing developments proved very similar to Etrimo's in terms of dwelling arrangements and consolidated the grip of pragmatic modernism in the city (Figure 8).

Despite its utterly pragmatic plans and identical buildings, Etrimo did achieve one of modernism's heroic dreams at the scale of the city. Indeed, the "buildings in a park" were designed in such a way that only a "maximum of $10 \%$ of the lots were built" (Etrimo, 1963, p. 18). Hence, the multiplication of Etrimo and Etrimolike developments in the second belt of the city (Figure 9) contributed to the elaboration of a park-city of housing, providing "cures of fresh air" for everyone (Etrimo, 1963, p. 16).

\section{From Innovative Models to Serial Products}

Although Bourgeois declared that the 'salvation of architecture is scarcity' (Bourgeois, 1922), it is precisely the 


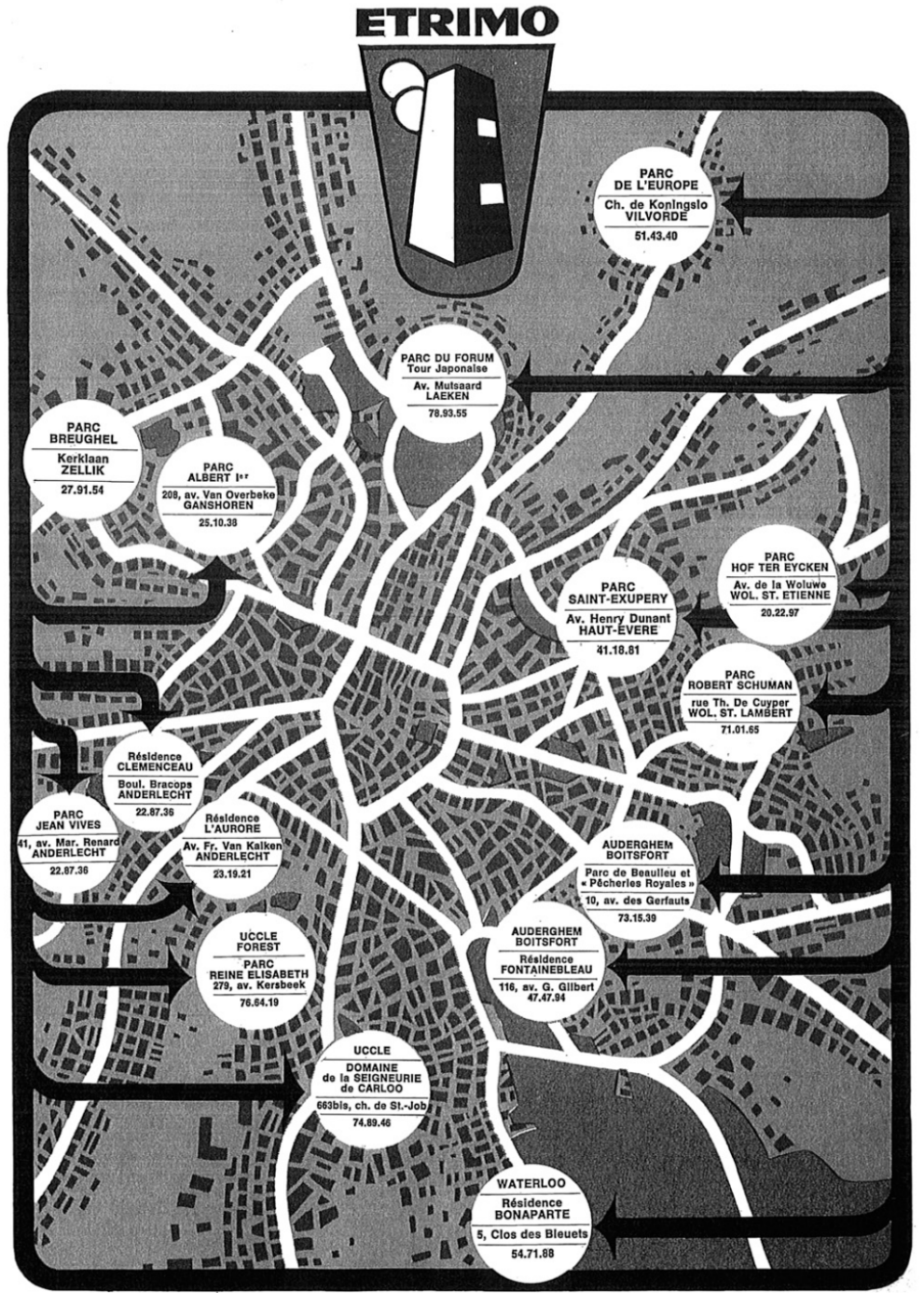

Figure 6. Etrimo, Sales brochure, 1960s. Source: courtesy of Pol Mertens, a former Etrimo administrator.

lack of economic means and political support that restrained its interbellum implementation. In Brussels, the modernist rhetoric was called upon to (re)construct the city after the war, affecting its territory in terms of urban planning and housing. However, the tangible projects differ from the initial rhetoric.

\subsection{Urban Scale}

The urban proposals of Bourgeois of the late 1920s and the Manhattan Plan differ significantly. Firstly, the agendas of the projects are entirely different. While Grand and Nouveau Bruxelles were meant to fuel the debate over the city's future, private developers saw in the Manhattan Plan very real and financial opportunities (Strauven, 2015). Secondly, the programs differ completely. Bourgeois's proposals relied primarily on housing as the fabric of the new neighbourhoods, faithful to the ideas of the CIAM in which dwelling was "the primordial element of urbanization" (Mumford, 2002, p. 90). Conversely, the Manhattan Plan was es- sentially meant as a business district with very little housing. Thirdly, the collective amenities planned in the first modernist projects were "left aside" to produce mono-functional venues deprived of their "original social idealism" (Smets, 1977, p. 148). Fourthly, the project stakeholders also varied. Indeed, modernist pioneers counted on strong public authorities to carry out their ideology. However, post-war projects were usually implemented by private developers because of anaemic urban planning policies designed to line individual pockets rather than benefit the city. Eventually, the tabula rasa advocated by modernist architects was implemented differently. Bourgeois suggested two attitudes: radical (Nouveau Bruxelles), and reforming (Grand Bruxelles). In the latter, even though an entire neighbourhood is torn down, he acknowledges the city's key axes (such as the diagonal Royal Axis or the Allée Verte). Thus, in Grand Bruxelles, the city centre was preserved and the "future was left open" (Bourgeois \& Flouquet, 1952). The Manhattan Plan, however, did not take the city's existing structure into account, only using the 

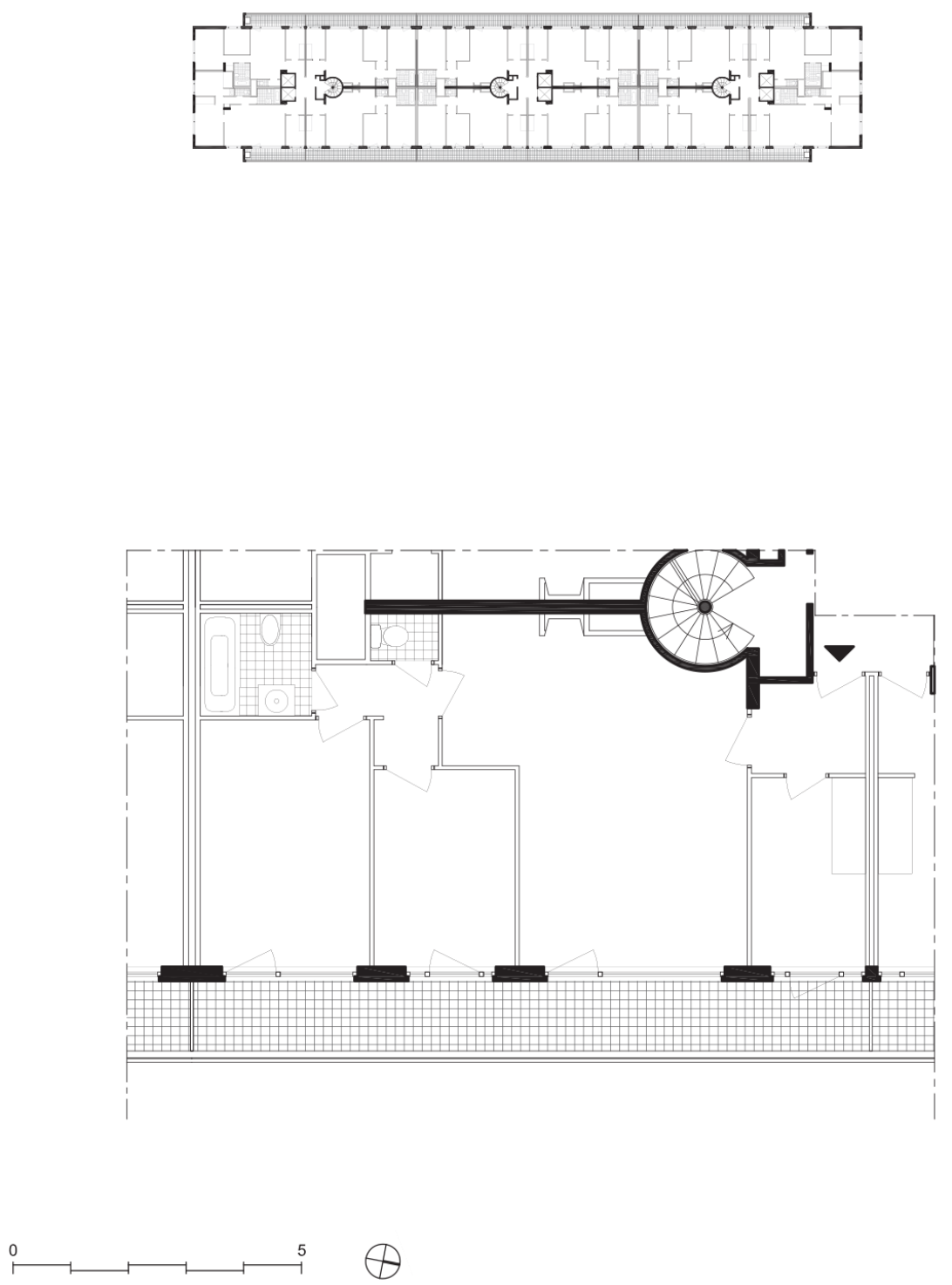

Figure 7. Etrimo, Parc Schuman, 1964 (drawings by the author).

Boulevard Jacqmain as a pretext to build a motorway along its axis. Finally, in the reforming plans of Grand Bruxelles, the features of the traditional city (streets and city blocks) were preserved, whereas they completely disappeared in the Manhattan Plan. Remarkably, the four functions of the functional city promoted by the CIAM-living, working, recreation and circulation-are addressed very differently by pre-war schemes as compared to post-war schemes. Indeed, while there is a balance between the four functions in the interbellum schemes, the Manhattan Plan places particular emphasis on work and circulation.

Similarities, however, also appear. Firstly, both preand post-war schemes embody the idea of Brussels as an international capital with all the requisite amenities. Secondly, both tear down an entire neighbourhood in the name of modernity. Thirdly, transport is a key element for both schemes, even though the proportion of public and private transport varies.

\subsection{Residential Scale}

Real estate developers made use of the ideas of modernism in the field of housing just as in urban planning. However, once again, several differences can be noted. Firstly, the pairing of Existenzminimum with a series of collective amenities was never implemented thoroughly. Post-war constructions simply piled up dwellings with little reflection on their collective nature. Secondly, as a corollary, post-war designs display larger dwelling surfaces than do Existenzminimum, enabling residents to stay at home rather than inducing them to experience collective amenities. Thirdly, the post-war interior typologies are a lot less innovative than their predecessors were. To reduce the technical shafts, the layouts of postwar apartments usually display clear night-day separations, with bedrooms gathered around the bathrooms and separate from living areas, which is technically efficient but not based on actual dwelling practices. Fourthly, 


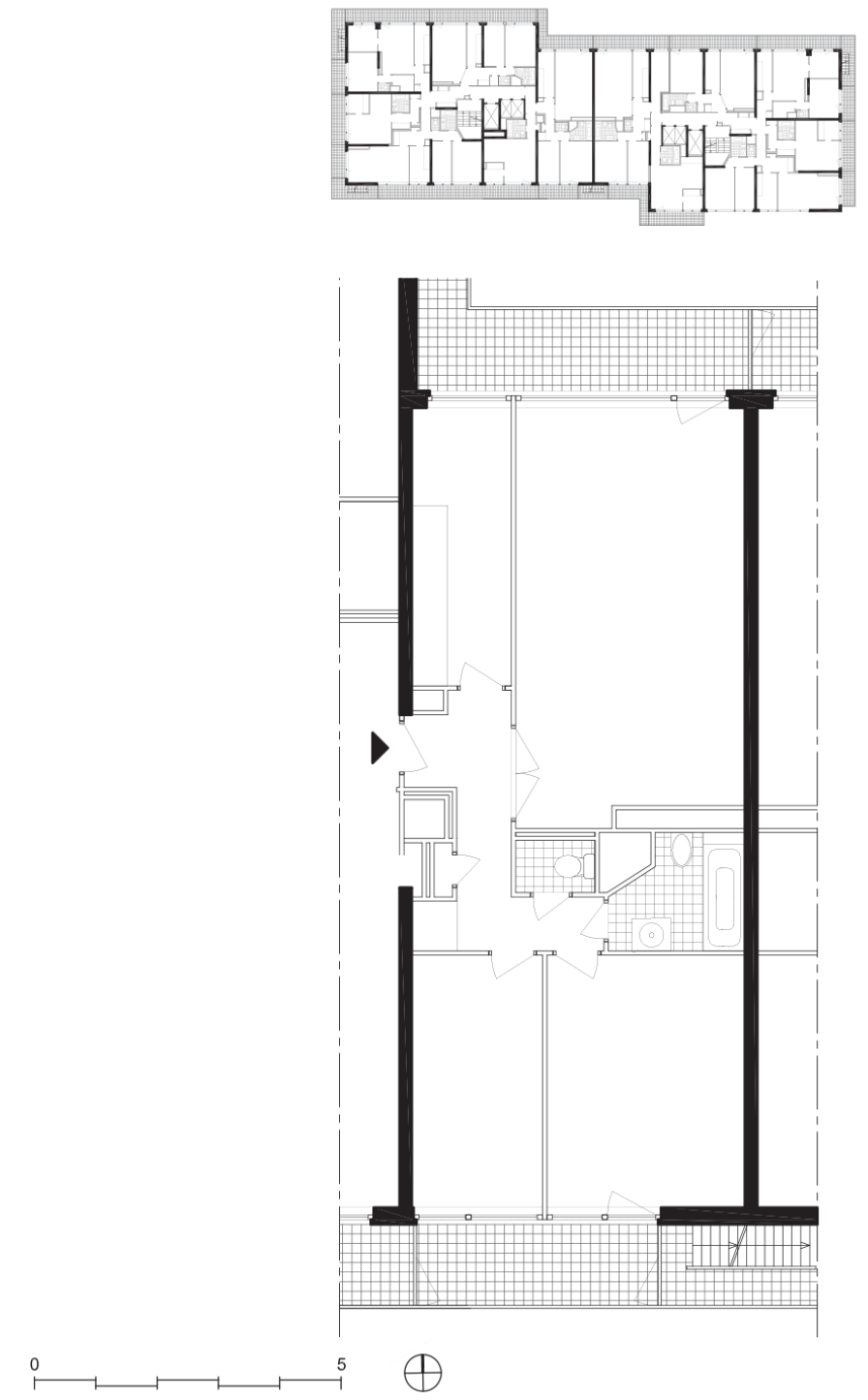

Figure 8. Amelinckx, Héliport, 1971 (drawings by the author).

all the multilevel innovations developed in pre-war layouts are replaced by mainly single-storey apartments. Finally, post-war buildings are usually a lot broader in order to maximise the number of built square meters and increase profit. These elements indicate a clear shift from inventive design in the interbellum to normative design in the post-war era. To build rapidly and in great numbers, post-war production was organized in series and based on norms (Delhaye, 1946; Mombach, 1948) that confirmed the modernist conception of the nuclear family as the basis for housing production. Nevertheless, despite these differences, post-war housing proved to be much more diverse and innovative in the public sector, as evidenced in the Cité Modèle or in the emblematic leder Zijn Huis in the North of Brussels. The Cité Modèle (Bernard, De Pange, Leclercq, \& Moutury, 2012) was built in the wake of the 1958 World Fair with the ambition to promote modernity in Belgium. It was built by a team of architects chosen from the country's three regions and obeyed the precepts of modernism to the letter. leder
Zijn Huis, for its part, is a free-standing housing slab built by Willy Van Der Meeren (De Kooning, 2012). The building was originally commissioned to Le Corbusier, who declined, offering Van Der Meeren the opportunity to design one of the most exemplary modernist buildings in Belgium. In both projects, features of the CIAM housing principles can be found: buildings raised on stilts, circulation areas as 'streets in the air', innovative duplex typologies, collective amenities on roof terraces, etc.

Yet, several formal and aesthetic similarities can be noted. Most important, both pre- and post-war housing typologies attempt to contradict traditional types. In Brussels, this is relevant in the morphology of the free-standing buildings, in the dwelling layouts that respond primarily to functions, and in the fact that dwelling becomes a "heteronomous production" (Pinson, 1989, p. 220), that is, completely detached from its future user.

Altogether, this evolution in urban and housing conceptions could be summarized as a shift from innovative models to serial products. The forms of modernism 


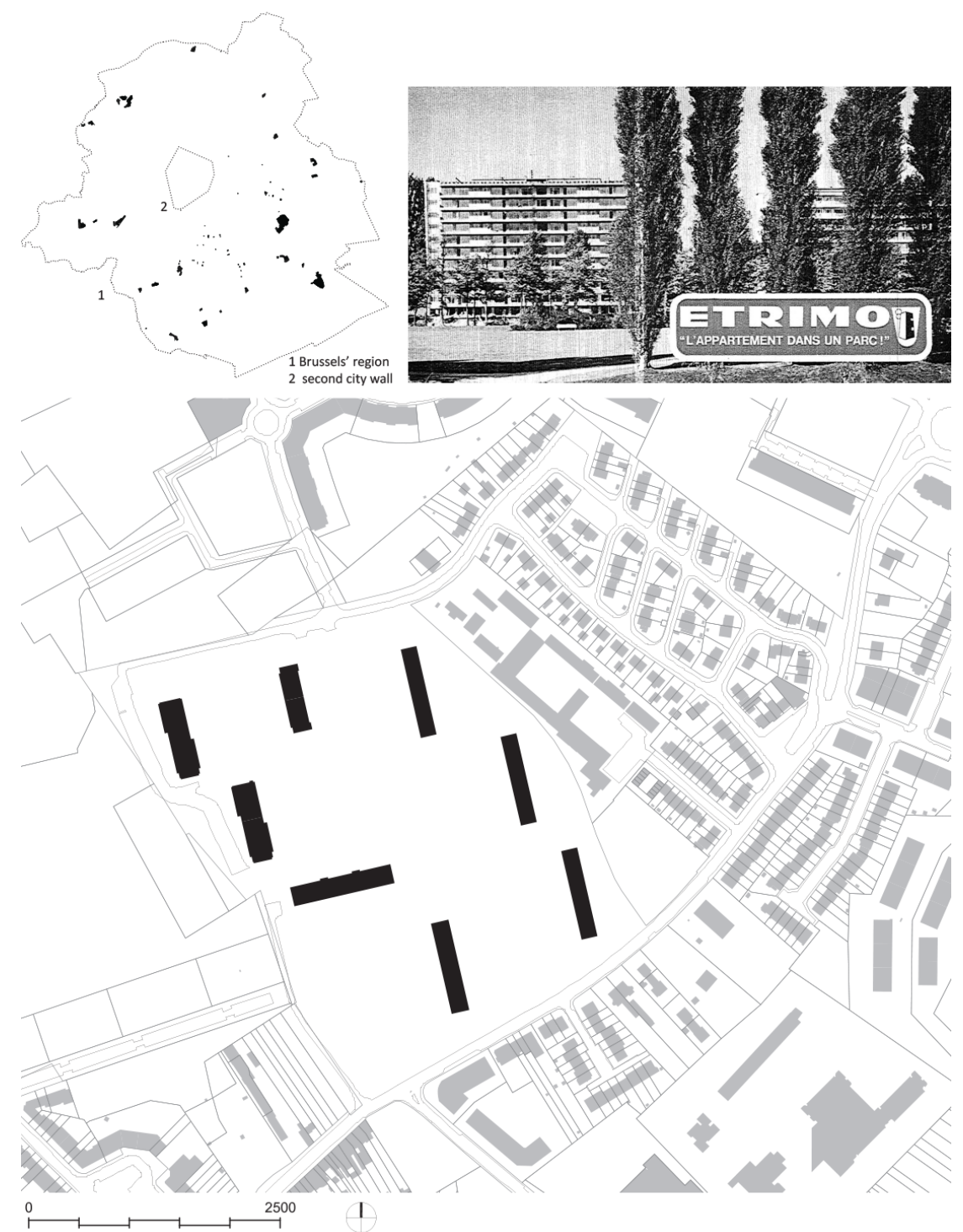

Figure 9. Etrimo's parcels in Brussels; Groupe Urbanisme, Parc Schuman, 1964 (drawings by the author; advertisement by Etrimo, 1965).

served to give the stamp of modernity to the reconstruction. In the "glorious thirties", rhetoric gave way to pragmatism, and the construction sector was primarily the business of state functionaries and private developers rather than architects. In these conditions, the "buildable replaced the habitable" (Chemetov, 2004, p. 10).

\section{Conclusion}

Modernist ideology turned its back on the conventions of the past, rejecting both traditional urban morphologies and housing types that echoed local conventions. In Brussels especially, pre-war CIAM ideas concerning urban planning and housing opposed the conventional ways of building in all respects. Modernism developed in two main stages in the city (Ledent, 2018). The first phase-heroic modernism-was mainly rhetorical, endeavouring to revolutionise ways of living. But the Great Depression hampered construction in the 1930s and heroic modernism impacted Brussels only marginally. The second wave-pragmatic modernism-relied mostly on systematization and codification, generating products according to norms. It was widely adopted to address post-war challenges but it "had lost its revolutionary meaning" (Smets, 1977, p. 164) and led to a "dull and grey pragmatism" (Beekaert \& Strauven, 1971). Although this reading might seem Manichean given that some protagonists were active in both periods and experienced a genuine evolution in their production (e.g., Etrimo), the comparison provides a useful tool to understand the issues of pre- and post-war housing and urban planning.

The CIAMs are exemplary of modernism not so much because they set the tone of how housing and urban planning were to be conceived, but because they were an "effort to more sharply delineate and promote directions already under way" (Mumford, 2002, p. 268). The first four meetings were very successful in the sense of defining the general views of modernism on housing and 
urban planning. However, and very paradoxically, while most pre-war CIAM members occupied "key positions in many Government Departments" in their countries after the war (Mumford, 2002, p. 169), they failed to unify their positions in the post-war meetings and put forward the underlying principles of reconstruction.

Two observations arise from the discrepancy between heroic and pragmatic modernism. On the one hand, modernism was diverted and remains therefore an "unfinished project" (Habermas, 1984). The ambitions and the generosity of the initial ideology, and more particularly the collective nature of the urban and residential projects, were left aside. This is mainly due to the stakeholders of post-war projects, who were mainly private. Indeed, as Bourgeois stated, modernism was supposed to serve the "common good" and "supersede private interests" (Smets, 1977, p. 150), but it did just the opposite: it served mainly the interests of large-scale developers that dismantled entire zones of the city. This phenomenon of Bruxellization represents this "profitdriven destruction of a city" (Doucet, 2012). Yet however good or evil the stakeholders were, their achievements need to be analysed rather than solely condemned. In addition, this opposition between the two eras could also simply be a sign of evolution in the ideas conveyed by modernism. While the collective nature or architecture and urbanism were prevalent in the pre-war period, individualization emerged after World War II, generating less collective projects.

On the other hand, heroic modernism contained flaws that would be confirmed in its execution. Among these is its relationship to the user. Indeed, while modernist ideology entrusted technique, comfort and hygiene to emancipate humans, its reality proved the opposite. From the end of the 1960 s, social crises exemplified the failure of modernism to address the diversity of society (Pinson, 2006). In Brussels, several projects were contested for their inability to generate urban inclusion, leading to the creation of grass-roots movements that claimed the "right to the city" (Patrimoine, 2017). In addition, lulled into the illusion of an undisputed answer to all human needs, modernism left little place for evolution. Its post-war offspring bore the same principles, blocking any possible evolution. Hence, modernist products were often unable to accommodate the variations of cultural conventions and their subsequent practices. These fundamental issues, coupled with the often poor quality of construction and energy consumption, led to a wide stigmatization of post-war projects and hence of modernism altogether. The CIAMs themselves addressed this specific shortcoming in their postwar congresses. In particular, the Constations of CIAM 4 which had become "the defining text of CIAM urbanism" (Mumford, 2002, p. 86), reducing urban planning to work, housing, recreation and transportation, became a major fixation. This four-pronged approach was severely criticized after the war by many CIAM members, including those of TEAM 10, who advocated thinking in terms of "living" and "scales of association" (Mumford, 2002, pp. 226-243). From then on, a new trend emerged, giving more attention to neighbourhood, community and people-centred design.

Nonetheless, the modernist project could be reconsidered without prejudice if the initial ideology was distinguished from what was built. Moreover, the actual potential of these projects must be recognized (robust construction, surrounding unbuilt spaces, efficient circulation, well-lit spaces, open views, hygiene, visual landmarks, etc.). Once these are acknowledged, it is possible to act with discernment and "build momentum on their unfinished aspects" (Druot, Lacaton, \& Vassal, 2007, p. 91). In this respect, the collective amenities that were left out could be added to the projects, though doing so effectively would require great political will on the part of public authorities. In addition, the design of such supplements should consider actual use. At the scale of housing in particular, attention to use recalls the first ambitions of modernism, which were to guarantee specific, minimum space for the household, alongside collective amenities. Interestingly, this attitude re-emerges in contemporary projects that reduce dwelling to its core while creating communal equipment. For the latter, however, lessons have to be learnt from the past by producing a great variety of dwelling typologies that address society's growing diversity, and creating collective amenities which were but a promise in the modernist project.

These elements point the way toward a possible rehabilitation of modernism through an objective rereading of both its heroic and pragmatic tendencies.

\section{Acknowledgments}

I wish to thank the reviewers for their valuable feedback, which helped to greatly improve the manuscript.

\section{Conflict of Interests}

The author declares no conflict of interests.

\section{References}

AAM. (1971). Victor Bourgeois, 1897-1962: Exposition rétrospective [Victor Bourgeois, 1897-1962: retrospective exhibition]. Ixelles: Archives d'Architecture Moderne.

Anonymous. (1929). L'architecture en Belgique. Quelques projets de l'architecte Victor Bourgeois [Architecture in Belgium. A few projects by the architect Victor Bourgeois]. La Cité, 7(11), 149-152.

Bauer, C. (1934). Modern housing. Cambridge: The Riverside Press.

Beekaert, G., \& Strauven, F. (1971). La construction en Belgique. 1945-1970 [Construction in Belgium. 1945-1970]. Anvers: Confédération nationale de la Construction.

Bernard, P., De Pange, I., Leclercq, J.-M., \& Moutury, S. 
(2012). La cité modèle à Bruxelles. Vie(s) d'un grand projet [The cité modèle in Brussels. Life(ves) of a great project]. Woluwe-Saint-Pierre: Aparté.

Bourgeois, V. (1922). Architecture [Architecture]. La Cité, 7, 149-151.

Bourgeois, V. (1927). L'urbanisme vivant. Pour le Grand Bruxelles. Quelques suggestions [Living urbanism. For the Great Brussels. A few suggestions]. 7 Arts, 5(14), 1-2.

Bourgeois, V. (1930). Le Grand Bruxelles [The great Brussels]. La Cité, 8(11), 165-180.

Bourgeois, V. (1931a). Habitations minima [Minimal dwellings]. L'émulation, 51(11), 391-414.

Bourgeois, V. (1931b). L'architecture moderne [Modern architecture]. Tekhne, 8, 165-169.

Bourgeois, V., \& Flouquet, C. (1952). Victor Bourgeois, architectures 1922-1952 [Victor Bourgeois, architectures 1922-1952]. Courtrai: Éditions Art et technique.

Braeken, J. (2003). Groupe structures. In A. Van Loo (Ed.), Repertorium van de architectuur in België van 1830 tot heden [Architecture directory in Belgium from 1830 to today] (pp. 326-327). Antwerpen: Mercatorfonds.

Brauman, A., Culot, P., Hoa, J.-P., Mierop, C., Paindaveine, H., \& Van Loo, A. (1982). L'immeuble et la parcelle. Les immeubles à appartements comme éléments constitutifs du tissu urbain. Le cas de Bruxelles. 1870-1980 [The building and the plot. Appartment buildings as constitutive elements of the urban fabric]. Brussels: Editions des Archives d'Architecture Moderne.

Broes, T., \& Dehaene, M. (2016). Real estate pioneers on the metropolitan frontier. The works of Jean-Florian Collin and François Amelinckx in Antwerp. Cidades, 2016(33). http://dx.doi.org/10.15847

Chemetov, P. (2004). Preface. In F. Dufaux \& A. Fourcaut (Eds.), Le monde des grands ensembles. France, Allemagne, Pologne, Russie, République Tchèque, Bulgarie, Algérie, Corée du Sud, Iran, Italie, Afrique du Sud [The world of the grands ensembles. France, Germany, Poland, Russia, Czech Republic, Bulgaria, Algeria, South Corea, Iran, Italy, South Africa]. Cachan: Editions Créaphis.

CIAM II. (1930). Die Wohnung für das Existenzminimum [The dwelling for minimal existence]. Frankfurt am Main: Englert \& Schlosser.

Collin, J.-F. (1938). L'épargne immobilière et sa fonction sociale [Real estate savings and its social function]. Paris: Librairie Générale de Droit et de Jurisprudence.

De Kooning, M. (2012). Willy Van Der Meeren: leder Zijn Huis, passé et futur d'une unité d'habitation à Evere [Willy Van Der Meeren: leder Zijn Huis, past and future of a housing unit in Evere]. Brussels: CIVA.

de Saulnier, P. (1963). Bruxelles à l'heure de la rénovation [Brussels at the age of renovation]. Habiter, 1963(December), 24-25.

Delhaye, J. (1946). L'appartement d'aujourd'hui [Today's apartment]. Liège: Desoer.

Demey, T. (1992). Bruxelles, chronique d'une capitale en chantier, de l'Expo '58, au siège de la C.E.E [Brussels, chronicle of a capital under construction, from Expo '58, at the headquarters of the E.E.C]. Bruxelles: Paul Legrain/CFC éditions.

Dessouroux, C. (2008). Espaces partagés, espaces disputés. Bruxelles, une capitale et ses habitants [Shared spaces, disputed spaces. Brussels, a capital and its inhabitants]. Brussels: Direction Études et Planification (AATL).

Doucet, I. (2012). Making a city with words: Understanding Brussels through its urban heroes and villains. City, Culture and Society, 3(2), 105-116.

Druot, F., Lacaton, A., \& Vassal, J. P. (2007). PLUS: Les grands ensembles de logements. Territoires d'exception [PLUS: The large housing estates. Exceptional territories]. Barcelona: Editions Gustavo Gili SL.

Etrimo. (1949). Un appartement. Des raisons de l'achat d'un appartement [An apartment. On the reasons to buy an apartment]. Brussels: Etrimo.

Etrimo. (1963). Comment devenir propriétaire [How to become a homeowner]. Brussels: Etrimo.

Etrimo. (1965). Parc Breughel [Breughel Park]. Brussels: Etrimo.

Giedion, S. (1931). Rationelle Bebauungsweisen: Ergebnisse des 3. Internationalen Kongresses für Neues Bauen, Brüssel, Nov. 1930 [Rational development: Results of the 3rd international congress for modern architecture, Brussels, Nov. 1930]. Stuttgart: Englert \& Schlosser.

Gropius, W. (1925a). Grundsätze der BauhausProduktion [Principles of Bauhaus production]. In W. Gropius (Ed.), Neue Arbeiten der Bauhauswerkstätten [New works of the Bauhaus workshops]. München: Bauhaus Bücher.

Gropius, W. (1925b). Wohnhaus-Industrie [Housing industry]. In A. Meyer (Ed.), Ein Versuchshaus des Bauhauses in Weimar [A Bauhaus experimental house in Weimar]. Weimar: Bauhaus Bücher.

Gropius, W. (1931). Flach-Mittel-Oder Hochbau? [Low, average, or high-rise building?]. In Internationale Kongresse für Neues Bauen (Ed.), Rationelle Bebauungsweisen; Ergebnisse des 3. Internationalen Kongresses für Neues Bauen, Brüssel, Nov. 1930 [Rational development: Results of the 3rd International Congress for Modern Architecture, Brussels, Nov. 1930]. Frankfurt am Main: Verlag Englert und Schlosser.

Habermas, J. (1984). Modernity: An unfinished project. In P. House (Ed.), Critical theory, the essential readings (pp. 158-169). New York, NY: Paragon House.

Hanrion, R. (2015). Belgique [Belgium]. Brussels: Seuil. Heynen, H. (2000). Architecture and modernity: A critique. Cambridge, MA: The MIT Press.

Hoste, H. (1937, March 20). Indien ik diktator was [If I was a dictator]. Nieuw Vlaanderen.

Hubert, M. (2008). Expo '58 and "the car as king". What 
future for Brussels's major urban road infrastructure? Brussels Studies, 2008(22), 1-17.

Ledent, G. (2014). Potentiels relationnels. L'aptitude des dispositifs physiques de l'habitat à soutenir la sociabilité. Bruxelles, le cas des immeubles élevés et isolés de logement [Relational potentials. The ability of the physical features of dwelling to support social skills. Brussels, the case of isolated high-rise housing buildings] (Unpublished Doctoral dissertation). UCLouvain, Louvain-la-Neuve.

Ledent, G. (2018). The standardization of housing. From heroism to flat pragmatism. In B. Burquel, T. de Roquemaurel, M. Dumon, \& G. Joachim (Eds.), Real estate architecture. The apartment building (pp. 91-112). Brussels: Real Estate Architecture.

Ledent, G., \& Komossa, S. (2019). Referential types as clues for housing design. Urban Morphology, 23(2), 1-18.

Martens, A. (2009). Dix ans d'expropriations et d'expulsions au Quartier Nord à Bruxelles (1965-1975): Quels héritages? [Ten years of expropriations and evictions in the Brussels North Quarter (1965-1975): What are the legacies today?]. Brussels Studies, 2009(29). Retrieved from https:// journals.openedition.org/brussels/685?lang=nl

Martens, A., \& Vanden Eende, M. (1994). Quartier Nord. Le relogement des expulsés [Brussels North Quarter. The reinstallation of displaced people]. Brussels: EPO.

Ministère des travaux publics et de la reconstruction. (1955). Bruxelles, carrefour de l'occident [Brussels, at the crossroad of the Western world]. Brussels: Ministère des Travaux Publics et de la Reconstruction.

Mombach, M. (1948). Plans minima. Première série. 1948-1949 [Minimal plans. First series. 1948-1949]. Brussels: Société Nationale des Habitations et Logement à Bon Marché.

Mumford, E. P. (2002). The CIAM discourse on urbanism, 1928-1960. Cambridge, MA: MIT Press.

Noël, F. (2009). Les politiques d'habitat [Housing policies]. Brussels: ULB.

Otlet, P. (1931). L'urbaneum [The urbaneaum]. La Cité, 9(10), 121-129.

Patrimoine, B.-U. e. (2017). Bruxelles, histoire de planifier: Urbanisme aux 19e et 20e siècles [Brussels, planning stories: Urbanism in the 19th and 20th centuries]. Brussels: Mardaga.

Pinson, D. (1989). Diffusion des modes de vie et brouillage des types architecturaux [Life style dissemination and blurring of architectural types]. Paper presented at the Actualité de la Typologie Architecturale, Centre de Recherche sur l'Habitat Ecole d'Architecture de Paris la Défense.

Pinson, D. (2006). De l'échec d'une charte à la poursuite d'une réflexion [From the failure of a charter to the pursuit of a reflection]. In Imbernon (Ed.), La Modernité critique, autour du CIAM 9 d'Aix-en-Provence, 1953 [Critical modernity, around CIAM 9 in Aix-enProvence, 1953] (pp. 241-257). Marseille: Editions Imbernon.

Romańczyk, K. M. (2012). Transforming Brussels into an international city: Reflections on 'Brusselization'. Cities, 29(2), 126-132.

Schoonbrodt, R. (1979). Sociologie de l'habitat social réflexion [Social housing sociology]. Gand: Editions des Archives d'Architecture Moderne.

Schoonbrodt, R. (2007). Vouloir et dire la ville: Quarante années de participation citoyenne à Bruxelles [To desire and to disclose the city: Fourty years of citizens' participation in Brussels]. Brussels: AAM.

Smets, M. (1977). L'avènement de la cité-jardin en Belgique, Histoire de l'habitat social en Belgique de 1830 à 1930 [The advent of the garden-city in Belgium, history of social housing in Belgium from 1830 to 1930]. Liège: Pierre Mardaga.

Steinmann, M. (1979). International congress for modern architecture. CIAM: Document 1928-1939. Basel: Birkhauser.

Strauven, F., \& Braem, R. (1985). René Braem: les aventures dialectiques d'un moderniste flamand [René Braem: the dialectic adventures of a Flemish modernist]. Brussels: Archives d'Architecture Moderne.

Strauven, I. (2015). Victor Bourgeois (1897-1962): Radicaliteit en pragmatisme. Moderniteit en traditie [Victor Bourgeois (1897-1962): Radicality and pragmatism. Modernity and tradition]. (Unpublished Doctoral dissertation). Ghent University, Ghent.

Strauven, I., Culot, M., \& De Gobert, P. (2005). Les frères Bourgeois: Architecture et plastique pure [The Bourgeois brothers: Architecture and pure platic art]. Barcelona: Editions des Archives d'Architecture Moderne.

Teige, K. (1932). The minimum dwelling. Cambridge, MA: MIT Press.

Verwilghen, R. (1934). Vers un urbanisme national? [Towards a national urbanism]. Bâtir, 25, 963-966.

Voyé, L. (1998). Sociologie: Construction du monde, construction d'une discipline [Sociology: building a world, building a discipline]. Brussels: De Boeck Université.

\section{About the Author}

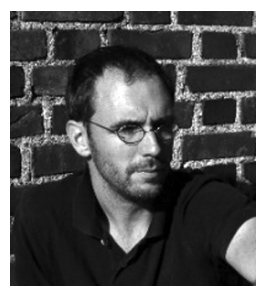

Gérald Ledent is an Architectural Engineer. He is an Associate Professor at UCLouvain in Brussels, where he teaches theory, as well as in various studios. He holds a PhD in architecture and plays a co-coordination role in the "Uses \& Spaces" research team, in which his research interests focus on the relationship in domestic architecture between uses and spaces, housing typo-morphologies and research by design. In addition, he has extensive experience in the fields of public buildings and collective housing developments in Belgium and abroad. He is also the co-founder of KIS studio (Keep It Simple studio), which aims to avoid unnecessary complexity in order to focus on essentials. 